\title{
INFLASI DAN NILAI TUKAR RUPIAH TERHADAP INDEKS SAHAM SYARIAH INDONESIA
}

\author{
Agus Fuadi \\ Universitas Pelita Bangsa \\ agus.fuadi@pelitabangsa.ac.id
}

\begin{abstract}
ABSTRAK
Indeks Saham Syariah Indonesia di Indonesia (ISSI) merupakan indikator kinerja pasar saham syariah di Indoneia, perkembangan saham syariah memperlihatkan trend positif. Pertumbuhan ISSI secara fluktuatif dipengaruhi oleh beberapa faktor, diantaranya faktor makro dan mikro ekonomi. Inflasi dan Nilai tukar merupakan faktor makro ekonomi yang mempengaruhi perkembangan saham, dimana ISSI merupakan indeks saham yang dipengaruhi oleh inflasi dan nilai tukar. Penelitian ini bertujuan untuk menganalisis pengaruh Inflasi dan nilai kurs terhadap Indeks Saham Syariah Indonesia. Metode yang digunakan dalam penelitian adalah metode kuantitatif. Perusahaan yang terdapat dalam ISSI menjadi populasi dalam penelitian, dan sampel yang digunakan melalui purposive sampling memperoleh data periode tahun 2014-2018. Analisis yang digunakan melalui uji f (simultan) dan uji t (parsial) menyimpulkan bahwa inflasi dan nilai tukar secara simultan berpengaruh terhadap ISSI. Uji secara parsial menunjukkan bahwa inflasi berpengaruh negatif terhadap ISSI, yang berarti bahwa semakin tinggi inflasi maka ISSI semakin rendah. Sedangkan nilai tukar rupiah tidak memiliki pengaruh terhadap ISSI.
\end{abstract}

Kata kunci: Inflasi, nilai tukar, Indeks Saham Syariah Indonesia (ISSI)

\begin{abstract}
The Indonesian Sharia Stock Index in Indonesia (ISSI) is an indicator of the performance of the sharia stock market in Indonesia, the development of sharia stocks shows a positive trend. The growth of ISSI fluctuatively is influenced by several factors, including macro and micro economic factors. Inflation and the exchange rate are macroeconomic factors that influence stock development, where ISSI is a stock index that is influenced by inflation and the exchange rate. This study aims to analyze the effect of inflation and the exchange rate on the Indonesian Syariah Stock Index. The method used in this research is quantitative method. The companies contained in ISSI became the population in the study, and the sample used through purposive sampling obtained data for the 2014-2018 period. The analysis used through the $f$ test (simultaneous) and t test (partial) concluded that inflation and the exchange rate simultaneously affect ISSI. The partial test shows that inflation has a negative effect on ISSI, which means that the higher the inflation, the lower ISSI. While the rupiah exchange rate has no influence on ISSI.
\end{abstract}

Keywords: Inflation, exchange rates, Indonesian Syariab Stock Index (ISSI)

\section{PENDAHULUAN}

Investasi di pasar modal adalah salah satu investasi yang mempunyai peran penting bagi perekonomian negara karena pasar modal menjalankan dua fungsi yaitu, sebagai sarana bagi pendanaan usaha (emite) dan sarana bagi perusahaaan untuk mendapatkan dana dari masyarakat pemodal (investor) (idx.co.id,2018). Pasar modal syariah adalah pasar modal yang melaksanakan tugasnya dengan prinsip syariah, setiap transaksi surat berharga dipasar modal dilakukan sesuai dengan ketentuan syariah (Sutedi, 2014).

Investasi syariah di pasar modal memiliki peran untuk mengembangkan pangsa pasar industri 


\section{JURNAL AKUNTANSI BISNIS PELITA BANGSA-VOL 5 NO. 1 - JUNI 2020}

keuangan syariah di Indonesia. Perkembangan pasar modal syariah di Indonesia semakin terkenal dengan adanya Indeks Saham Syariah Indonesia (ISSI) yang diterbitkan oleh Bapepam LK dan Dewan Syariah Nasonal Majelis Ulama Indonesia (DSN-MUI) pada tanggal 12 Mei 2011 (Sutendi,2014).

Indeks Saham Syariah Indonesia (ISSI) merupakan indikator dari kinerja pasar saham syariah Indonesia yang diluncurkan pada tanggal 12 Mei 2011. Konstituen ISSI adalah seluruh saham syariah yang telah tercatat di BEI dan masuk ke dalam Daftar Efek Syariah (DES) yang diterbitkan oleh OJK. Artinya, BEI tidak melakukan seleksi saham syariah yang masuk ke dalam ISSI. Konstituen ISSI diseleksi ulang sebanyak dua kali dalam setahun, setiap bulan Mei dan November, mengikuti jadwal review DES. Oleh sebab itu, setiap periode seleksi, selalu ada saham syariah yang keluar dan masuk menjadi konstituen ISSI. Metode perhitungan ISSI mengikuti metode perhitungan indeks saham BEI lainnya, yaitu rata-rata tertimbang dari kapitalisasi pasar dengan menggunakan data Desember 2007 sebagai tahun dasar perhitungan ISSI (idx.co.id,2018). Pasar modal syariah bertugas sebagai penghubung antara para pihak investor dengan perusahaan ataupun institusi pemerintah melalui perdagangan instrumen jangka panjang seperti obligasi, saham, dan lain-lainnya.

Saham adalah untuk mendapatkan dana dari kegiatan investasi yang dilakukan penanam modal (Investor), yang membiayai jalannya operasional perusahaan dan memperluas usaha bagi perusahaan (Jogiyanto,2017). HargA sebuah saham sangat dipengaruhi oleh hukum permintaan dan penawaran, Harga saham naik apabila suatu saham mengalami kelebihan permintaan dan turun jika terjadi kelebihan penawaran (Umam dan Sutanto, 2017). Harga saham merupakan harga pasar yang tercatat setiap hari pada waktu penutupan (closing price) dari suatu saham. Harga saham adalah nilai sekarang atau present value dari aliran kas yang diharapkan diterima (Sartono,2017).

Pergerakan harga di pasar saham sangat sulit ditebak. Karena Saham dikenal dengan krakteristik "high risk-high return" yang merupakan resiko tinggi yang dimiliki pada surat berharga tetapi memberikan peluang keuntungan yang baik. Saham memberikan pemodal mendapatkan return atau keuntungan (capital gain) dengan jumlah yang cukup besar dalam jangka waktu yang singkat (Supramono, 2014).

Perkembangan saham syariah yang terdaftar di ISSI memperlihatkan trend positif. Pada setiap tahunnya pertumbuhan saham syariah selalu mengalami pertumbuhan yang fluktuatif, Dilihat dari kapitalisasinya berdasarkan data Otoritas Jasa Keuangan (OJK) Juni 2019, kapitalisasi saham syariah secara keseluruhan tercatat Rp. 3.699 triliun, menurun dibandingkan kapitalitas tahun 2018 sebesar Rp. 3.666 triliun (ojk.go.id,2019). Jumlah saham syariah yang tercatat berdasarkan Salinan Keputusan Dewan Komisioner Otoritas Jasa Keuangan yang berlaku mulai 1 Desember 2018 (Periode 2) adalah 420 saham dari sebelumnya berdasarkan Salinan Keputusan Dewan Komisioner Otoritas Jasa keuangan Nomor KEP-29/D.04/2019 Tentang Daftar Efek Syariah Dewan Komisioner Otoritas jasa keuangan yang berlaku mulai 1 Juni 2019 (Periode 1) adalah 419 saham(ojk.go.id,2019).

Dilihat dari kapitalitas Indeks Saham Syariah Indonesia (ISSI) di OJK yang mengalami perkembangan signifikan hal tersebut tentu dipengaruhi beberapa faktor, diantara faktor-faktor tersebut sangat penting yang mampu mempengaruhi perkembangan saham yaitu makro ekonomi seperti Inflasi, Nilai Tukar dan lain- lain (Qomariyah,2018)

Inflasi diartikan sebagai kenaikan harga secara umum dan terus menerus dalam jangka waktu tertentu. Kenaikan harga dari satu atau dua barang saja tidak dapat disebut inflasi kecuali bila kenaikan itu meluas (atau mengakibatkan kenaikan harga) pada barang lainnya. Deflasi adalah kebalikan dari inflasi. Indikator yang sering digunakan untuk mengukur tingkat inflasi adalah Indeks HargaKonsumen(IHK).PerubahanIHKdariwaktukewaktumenunjukkanpergerakan harga dari barang dan jasa yang dikonsumsi masyarakat. Penentuan barang dan jasa dalam keranjang IHK dilakukan atas dasar Survei Biaya Hidup (SBH) yang dilaksanakan oleh Badan Pusat Statistik (BPS). Kemudian, BPS akan memonitor perkembangan harga dari barang dan jasa tersebut secara bulanan di beberapa kota, di pasar tradisional dan modern terhadap beberapa jenis barang/jasa di setiap kota (bi.go.id,2018). Selain pergerakan inflasi, variabel makro lain yang menarik untuk dikaji yaitu nilaitukar.

Nilai tukar (kurs) merupakan harga suatu uang relatif terhadap mata uang Negara lain (Ekananda,2014). Kurs mempunyai peranan penting dalam keputusan - keputusan pembelanjaan, 
karena kurs memungkinkan kita menerjemahkan harga - harga dari berbagai Negara ke dalam satu bahasa yang sama dan mengetahui melemahnya nilai rupiah terhadap dollar akan berdampak pada perusahaan. Perusahaan yang mempunyai utang luar negeri dan melakukan kegiatan impor akan mengalami peningkatan beban produksi maupun kerugian karena selisih kurs. Hal ini menyebabkan laba perusahaan mengalami penurunan. Penurunan laba akan menyebabkan menurunnya kepercayaan investor terhadap perusahaan. Sehingga akan menurunkan harga saham, yang akan menyebabkan indeks saham syariah juga akan mengalami penurunan (Gumilang dan Hidayat, 2014).

Penelitian ini ditujukan untuk mengukur dan menjelaskan pengaruh variabel inflasi, dan nilai tukar terhadap Indeks Saham Syariah Indonesia (ISSI) agar para investor mampu menentukan langkahlangkah terbaik dalam pengambilan keputusan berinvestasi. Indeks Saham Syariah Indonesia dibuat untuk memberi jawaban kepada masyarakat yang ingin mengetahui kinerja seluruh saham syariah sehingga akan memudahkan bagi pelaku pasar modal dalam mengukur kinerja saham syariah.

\section{KAJIAN PUSTAKA}

Pasar modal syariah dilaksanakan berdasarkan Prinsip-prinsip Syariah di Pasar Modal. Berdasarkan Peraturan Bapepam-LK Nomor IX.A.13, Prinsip- prinsip Syariah di Pasar Modal adalah Prinsip hukum Islam dalam kegiatan pasar modal yang berdasarkan fatwa Dewan Syariah Nasional Majelis Ulama Indonesia (DSN-MUI), sepanjang fatwa tersebut tidak bertentangan dengan Peraturan ini dan/atau Peraturan Bapepam-LK yang didasarkan pada fatwa DSN-MUI (Umam dan Susanto,2017 :79).

Indeks saham di Bursa Efek Syariah Indonesia, seleksi saham, Bursa Efek Indonesia memiliki Komite Penasihat yang memiliki enam antara lain yaitu: (Jogianto,2017: 166)

1. Indeks Harga Saham Individu (IHSI) atau indeks saham individu adalah indeks yang harganya masing-masing harga pasar saham terhadap harga dasar saham.

2. Indeks Harga Saham Gabungan (IHSG) diperkenalkan tanggal 1 April 1983. IHSG mencakup seluruh pergerakan harga saham dan berbagai jenis saham, baik saham biasa maupun preferen, yang terdaftar di Bursa EfekIndonesia.

3. Indeks Sektoral, diperkanalkan tanggal 2 Januari 1996. Indeks sektoral merupakan bagian IHSG. Semua perusahaan yang tercatat di Bursa Efek Indonesia diklasifikasikan dalam 9 sektor berdasarkan klasifikasi industri. Klasifikasi in ditetapkan oleh Jakarta Stock Exchange Industrial Classification (JASICA).

4. Indeks LQ45, diperkenalkan tanggal 13 Juli 1994. Indeks LQ45 terdiri atas 45 saham yang dipilih setelah melalui seleksi beberapa kriteria tertentu, sehingga indeks ini terdiri atas saham yang mempunyai kriteria luquiditas tinggi dan kapitalisasi pasar tinggi. Untuk menjamin kewajaran dalam terdiri atas kalangan praktisi, akademisi dan profesional independen dibidang pasarmodal.

5. Indeks Saham Syariah, adalah indeks yang pelaksanaanya berprinsip menurut syariat Islam dengan melakukan setiap aktivitas, seperti: Jakarta Islamic Index (JII) dan Indeks Saham Syariah Indonesia(ISSI).

6. Indeks papan utama (Main Board Index), dan Indeks Papan pengembangan (Development BoardIndex).

\section{Indeks Saham Syariah Indonesia(ISSI)}

Indeks Saham Syariah Indonesia (ISSI) merupakan indikator dari kinerja pasar saham syariah Indonesia. Indeks ini diluncurkan oleh IDX pada tanggal 12 Mei 2011. Indeks ini berisi dengan sahamsaham yang berada di daftar Efek Syariah (DES) yang dikeluarkan sesuai regukasi Bapepam-LK No. II.K.1 setiap 6bulannya di mulai Mei dan November. Tanggal basis yang digunakan adalah Desember 2007 dengan nilai 100. Indeks ini dihitung sama dengan perhitungan IHSG yaitu menggunakan cara rata-rata timbangan kapitalisasi pasar (value weighted) (Jogianto, 2017 :177-178).

Kriteria saham-saham yang dapat masuk ke indeks sesuai dengan regulasi Bapepam-LK No.11, K.1 adalah sebagai berikut:

a. Perusahaan Yang Tidak Melakukan Kegiatan Prinsip Syariah 
b. Perusahaan yang tidak melakukan kegiatan-kegiatan usaha yang bertentangan dengan prinsipprinsip Syariah sebagaimana dimaksud dalam angka 2 huruf a Peraturan Nomor IX.A.13 sebagai berikut.

1. Perjudian dan permainan yang tergolong judi atau perdagangan yang dilarang.

2. Perdagangan yang dilarang menurut syariah,semacam:

a. Perdagangan yang tidak diikuti oleh pengiriman/transfer barang-barang dan ataujasa-jasa.

b. Perdagangan penawaran dan permintaanpals

c. Menyelenggarakan jasa keuangan yang menerapkan konsepribawi,semacam:Bank berbasis suku bunga,danPerusahaan keuangan berbasis sukubunga.

d. Jual beli risiko yang mengandung spekulasi (gharar) dan perjudian (maysir).

e. Memproduksi, mendistribusikan, memperdagangkan, danmenyediakan:

a) Barang dan jasa yang haram karena zatnya (haramli-dzatihi);

b) Barang dan jasa yang ditetapkan oleh DSN-MUI;dan

c) Barang dan jasa yang merusak moral dan bersifat mudarat;dan

3. Transaksi-transaksi yang mengandung elemen penyuapan(risywah).

c. Perusahaan-perusahaan memenuhirasio-rasio keuangan sebagai berikut:

1. Total hutang yang berbasis bunga dibandingkan dengan total aktiva tidak lebih dari45\%.

2. Total pendapatan bungan dan pendapatan tidak halal lainnya dibandingkan dengan total

Inflasi pendapatan (revenue) tidak lebih dari10\%.

Inflasi dapat diartikan sebagai kenaikan harga secara umum dan terus menerus dalam jangka waktu tertentu. Kenaikan harga dari beberapa barang saja tidak dapat disebut inflasi kecuali bila kenaikan itu meluas (atau mengakibatkan kenaikan harga) pada barang lainnya (bi.go.id,2005).

Indikator yang sering digunakan dalam mengukur tingkat inflasi Indeks Harga Konsumen (IHK) untuk Perubahan IHK dari waktu ke waktu menunjukan pergerakan harga dari barang dan jasa yang dikonsumsi masyarakat. Penentuan barang dan jasa dalam ruang IHK dilakukan atas dasar Survei Biaya Hidup (SBH) yang dilaksanakan oleh Badan Pusat Statistik (BPS). Kemudian, BPS akan memonitor perkembangan harga dari barang dan jasa tersebut setiap bulannya di beberapa daerah, antara lain pasar tradisional dan modern terhadap beberapa jenis barang/jasa di setiap daerah (bi.go.id,2005).

Pengelompokaninflasi

Berdasarkan The Classification of individual consumption by purpose- COICOP, Inflasi yang diukur dengan IHK di Indonesia dikelompokan ke dalam 7 kelompok pengeluaran yaitu (Indonsia.B, 2005) :

a. Kelompok bahanmakanan

b. Kelompok makanan jadi, seperti minuman, rokok danlainnya

c. Kelompok perumahan, air, listrik gas, dan bahanbakar

d. Kelompoksandang

e. Kelompokkesehatan

f. Kelompok pendidikan, rekreasi dan olahraga

g. Kelompok Transpor, Komunikasi, dan JasaKeuangan

Berdasarkan pengelompokan COICOP tersebut, BPS saat ini juga telah mempublikasikan inflasi sesuai dengan pengelompokan yang lainnya yang dinamakan disagregasi inflasi. Disagregasi inflasi dilakukan untuk menghasilkan suatu indikator inflasi yang lebih menggambarkan pengaruh dari faktor yang bersifatfundamental.Di Indonesia, disagregasi Inflasi IHK tersebut dikelompokan menjadi (Indonesia.B, 2005) :

1. Inflasi Inti, yaitu komponen inflasi yang cenderung menetap atau persisten (persistent component) di dalam pergerakan inflasi dan dipengaruhi oleh faktor fundamental, seperti:

a. Interaksipermintaan-penawaran

b. Lingkungan eksternal: nilai tukar, harga komoditi internasional, Inflasi mitradagang

c. Ekspektasi inflasi dari pedagang dankonsumen

2. Inflasi non Inti, yaitu komponen inflasi yang cenderung tinggi volatilitasnya karena dipengaruhi 
oleh selain faktor fundamental. Komponen inflasi non inti terdiri dari:

a. Inflasi Komponen Bergejolak (Volatile Food) : Inflasi yang dominandipengaruhi oleh shocks (kejutan) dalam kelompok bahan makanan seperti panen, gangguan alam, atau faktor perkembangan harga komoditas pangan domestik maupun perkembangan harga komoditas panganinternasional.

b. Inflasi Komponen Harga yang diatur Pemerintah (Administered Prices): Inflasi yang dominan dipengaruhi oleh shocks (kejutan) berupa kebijakan harga Pemerintah, seperti harga BBM bersubsidi, tarif listrik, tarif angkutan,dll.

\section{Nilai Tukar Rupiah}

Nilai Tukar suatu mata uang merupakan tingkat harga pertukaran dari satu mata uang ke mata uang yang lainnya yang dapat digunakan dalam berbagai transaksi, antara lain transaksi perdagangan internasional, turisme, dan investasi internasional, ataupun bisa aliran uang jangka pendek antarnegara, yang melewati batas-batas geografi ataupun batas-batas hukum. Harga tersebut menggambarkan berapa banyak suatu mata uang harus dipertukarkan untuk memperoleh satu unit mata uang lain. Istilah lain nilai tukar adalah Rasio Pertukaran (Karim,2015:157).

Nilai Tukar riil adalah harga relatif dari barang - barang kedua negara, yang menyatakan tingkat di mana kita dapat memperdagangkan barang - barang dari suatu negara untuk barang - barang dari negara lain. Nilai Tukar Riil independen dapat dihitung dengan persamaan sebagai berikut:

\section{Nilai tukar riil $=\underline{\text { Nilai tukar nominal } x \text { Harga barang domestik }}$}

\section{Harga barang luar Negeri}

Faktor yang Mempengaruhi Menguatnya KursValuta Asing suatu Negara, menurut (Haryajid, Hendy, dan Anjar, 2016 :42-42) Kurs Valas suatu Negara bertambah kuat jika:

a. Ekspor lebih besar dari padaimpor

b. Neraca pembayaransurplus

c. Neraca pertumbuhansurplus

d. Pertumbuhan ekonomimeningkat

e. Tingkat inflasi yang rendah dan lain-lain.

Di samping lima faktor ini sebenarnya ada faktor lain yang harus ikut dimiliki oleh suatu Negara, yaitu:

1. Cadangan valas yangmencukupi,

2. Kualitas konstruksi manajemen keuangan internasional yang memiliki daya tahan secara jangkapanjang,

3. Kualitas Sumber Daya Manusia (SDM) yang siap bangkit kembali jika suatu saat terjadi krisis moneterinternasional,

4. Dewan moneter nasional yang dibentuk oleh pemerintah yang suatu diisi oleh mereka-mereka yang memiliki reputasi internasional dan jauh dari intervensi para politisi serta parapebisnis.

5. Jumlah hutang dalam bentuk Foreign currency baik oleh pemerintah maupun swasta adalahkecil.

Model Penentuan NilaiTukar

Menjelaskan tentang model penentuan nilai tukar yang dipakai, yaitu: (Fei Ming,2016 :45)

Traditional Theories

Terdiri dari Teori Purchasing Power Party dan Teori Elastisitas:

a. Teori Purchasing PowerParty

Teori ini merupakan teori tertua dan terpopuler. Teori ini pertama kali diperkenalkan pada tahun 1556 oleh Martin de AzpilcuetaNavarro.Dalam teori ini menjelaskan bahwa harga barang di suatu Negara harus sama dengan harga barang serupa di negara lain sesuai dengan tingkat nilai tukar yang berlaku antar kedua negara tersebut. Terdapat dua versi dalam teori Purchasing Power Parity (Fei Ming,2016:44): 
1. Veris Absolut

Dalam teori versi absolut, Perbandingan nilai tukar sama dengan perbandingan antara tingkat harga umum yang berlaku di dua Negara, yang merupakan rata - rata tertimbang (weighted average) dari seluruh produk yang dihasilkan kedua Negara.

2. VersiRelatif

Dalam teori versi relatif, persentase perubahan nilai tukar pada waktu yang di tentukan sebagai periode dasar harus sama dengan perbedaan antara persentase perubahan harga (tingkat inflasi) domestik dengan persentase perubahan harga (tingkat inflasi) di luar negeri pada periodetersebut.

b. Teori Elastisitas

Teori elastisitas mengatakan bahwa nilai tukar adalah harga dari valuta asing untuk mempertahankan neraca pembayaran internasional suatu Negara agar tetap berada pada tingkat ekuilibrium (Fei Ming,2016 :44).

1. Modern Monetary Theories on Short Term Exchange Rate Volatility Mengemukakan teori ini memperhatikan adanya peran pasar modal dalam jangka pendek dan peran bursa komoditi dalam jangka panjang terhadap fluktuasi nilai tukar (Karim,2015:157)

2. Synthesis of Traditional and Modern MonetaryViews

Menjelaskan menurut teori ini, dinamika perubahan yang terjadi di pasar keuangan (pasar modal dan pasar uang) lebih cepat jika dibandingkan dengan perubahan di pasar barang/komoditi (Ming,2016).

\section{HIPOTESIS}

Berdasarkan kajian pustaka dan inkonsistensi penelitian terdahulu, penulis membuat kerangka pemikiran dalam bentuk model penelitian sebagai berikut:

Gambar 1

Kerangka Penelitian

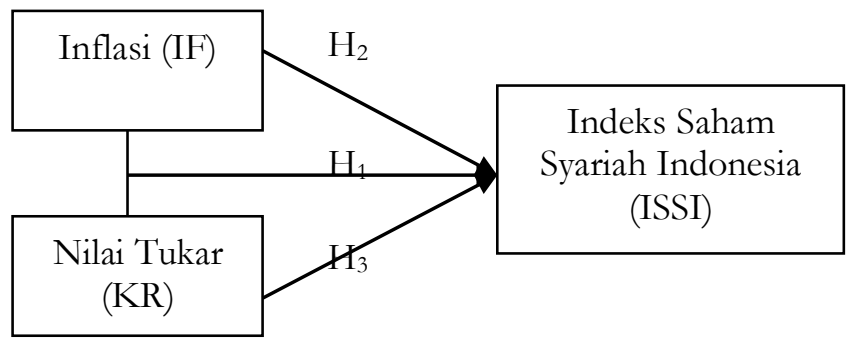

Sumber: Data diolah penulis, 2019

\section{Pengaruh Inflasi dan Nilai Tukar Rupiah terhadap Indeks Saham Syariah Indonesia(ISSI)}

Tingkat Inflasi yang tinggi biasanya dikaitkan dengan kondisi ekomoni yang terlalu panas, artinya kondisi ekonomi mengalami tingkat permintaan yang sangat tinggi melebihi kapasitas produksinya sehingga harga - harga cenderung mengalami kenaikan. Inflasi yang tinggi juga akan menyebabkan penurunan daya beli para investor untuk berinvestasi di pasar modal. Sedangkan nilai tukar sangat mempengaruhi jumlah biaya yang harus dikeluarkan. Kestabilan nilai tukar rupiah ditentukan oleh mekanisme pasar (free floating system), maka stabilan nilai rupiah lebih banyak ditunjukan kepada rendah dan stabilnya laju inflasi.

Fluktuasi kurs yang tidak stabil akan dapat mengurangi tingkat kepercayaan investor asing terhadap sektor ekonomi yang selanjutnya akan menimbulkan dampak negatif terhadap perdagangan saham di pasarmodal. Tingkat kenaikan dan penurunan ISSI dipengaruhi oleh naik dan turunnya inflasi dan nilai tukar (Widyasa dan Worokinasih, 2018), (Mulyani, 2012), (Ulandari, 2017),(Qomariyah,2018). Namun terdapat perbedaan yang menyatakan bahwa kenaikan ISSI akibat penurunan Inflasi dan nilai tukar, begitupun ketika ISSI turun dibarengi dengan kenaikan inflasi dan nilai tukar (Anggraeni, 2017). Serta 
adanya inkosistensi penelitian terdahulu yang menyatakan bahwa ISSI tidak dipengaruhi oleh inflasi dan nilai tukar (Suciningsih dan khoirol, 2015). Atas dasar inkonsistensi penelitian maka dapat dirumuskan hipotesis penelitian sebagai berikut:

$\mathbf{H}_{1}$ : Inflasi dan Nilai Tukar Rupiah berpengaruh terhadap Indeks Saham Syariah Indonesia (ISSI) secara simultan.

\section{Pengaruh Inflasi Terhadap Indek Saham Syariah Indonesia (ISSI)}

Tandelilin, 2010 :343 dalam (Rachmawati Martien dan Nisful Laila, 2015:938) mengatakan bahwa "Peningkatan inflasi secara relatif akan membawa sinyal negatif begi pemodal di pasar modal. Oleh karenanya, inflasi juga bisa disebut sebagai risiko daya beli. Jika inflasi mengalami peningkatan, investor biasanya menuntut biaya tambahan premium inflasi untuk mengkompensasi penurunan daya beli yang dialaminya.Inflasi memberikan pengaruh yang signifikan terhadap pergerakan harga saham yang terdapat di ISSI. Asumsi yang tepat yaitu ketika inflasi terjadi secara cepat dan meningkat tajam dari sebelumnya, minat investor untuk berinvestasi akan berkurang. Menurunnya minat investor untuk berinvestasi akan menurunkan harga saham perusahaan dan menurukan indeks saham (Utami dan Herlambang,2016).

Berdasarkan penelitian terdahulu mengenai variabel Inflasi berpengaruh negatif terhadap ISSI (Agestiani dan Sutanto,2019), dan Inflasi pengaruh negatif signifikan terhadap ISSI (Suciningtia dan khoiroh,2015), Inflasi berpengaruh dan signifikan terhadap harga saham di ISSI (Yuniarti dan Litriani,2017). Variabel Inflasi tidak berpengaruh signifikan terhadap ISSI (Avenda,2019), variabel inflasi tidak memiliki pengaruh terhadap ISSI (Khomaria,2018), Inflasi secara parsial tidak berpengaruh signifikan terhadap ISSI (Widyasa dan Worokinasih,2018), Inflasi tidak ada pengaruh signifikan terhadap ISSI, Inflasi berpengaruh positif terhadap ISSI (Mulyani,2012), dan Inflasi berpengaruh signifikan terhadap ISSI (Wahid, 2018), Inflasi berpengaruh dan signifikan terhadap Y (Ulandari, 2017).Sehubungan dengan hal tersebut maka pengembangan hipotesis penelitian dapat dirumuskan sebagai berikut :

$\mathbf{H}_{2}$ : Inflasi memiliki pengaruh positif dan signifikan terhadap Indeks Saham Syariah Indonesia (ISSI).

\section{Pengaruh Nilai Tukar RupiahTerhadap Indeks Saham SyariahIndonesia (ISSI)}

Nilai Tukar adalah Kenaikan yang menyeluruh dari jumlah uang yang harus dibayarkan (nilai unit penghitungan moneter) terhadap barang- barang/komoditas dan jasa (Karim,2015 :135). Risiko nilai tukar (kurs) berkaitan dengan fluktuasi nilai tukar mata uang domestik (negara perusahaan tersebut) dengan nilai mata uang negala lain. Risiko ini juga dikenal sebagai risiko mata uang (currency risk) atau risiko nilai tukar (exchange rate risk) (Tandelilin, 2001).Suciningtyas dan Khoiroh (2015) mengatakan jika mata uang mengalami depresiasi, perusahaan yang memiliki utang luar negeri dan yang perusahaan melakukan kegiatan impor akan terkena dampaknya. Perusahaan akan menanggung biaya yang lebih tinggi dari semula karena adanya pelemahan mata uang domestik, adanya peningkatan biaya tentu akan mengurangi laba perusahaan. Sehingga harga saham perusahaan akan mengalami penurunan, ketika harga saham mengalami penurunan akan mengakibatkan indeks saham ISSI juga mengalami penurunan.

Hasil penelitian terdahulu mengenai Variabel Nilai tukar berpengaruh signifikan terhadap ISSI (Avenda, 2019), Nilai tukar berpengaruh signifikan dan memiliki hubungan negatif terhadap ISSI (Sari,tyas dan Fathon, 2017), Penelitian nilai tukar berpengaruh dan signifikan terhadap ISSI (Yuniarti dan Litriani, 2017), Nilai tukar berpengaruh signifikan dan memiliki hubungan negatif terhadap ISSI (Widyasa dan Worokinasih, 2018), Nilai tukar berpengaruh negatif terhadap ISSI (Mulyani, 2012), Nilai Tukar tidak berpengaruh terhadap ISSI (Agnestiani dan Susanto, 2019), Nilai Tukar berpengaruh negatif signifikan terhadap ISSI (Suciningtia dan khoiroh, 2015), Nilai tukar (kurs) memiliki pengaruh negatif terhadap ISSI (Khomariah, 2018), Nilai tukar berpengaruh dan signifikan terhadap ISSI (Ulandari,2017), Nilai tukar berpengaruh negatif dan signifikan terhadap ISSI(Angggraeni,2017).

Variabel Nilai Tukar Rupiah berpengaruh dan signifikan terhadap harga saham di Indeks Saham 
JURNAL AKUNTANSI BISNIS PELITA BANGSA-VOL 5 NO. 1 - JUNI 2020

Syariah Indonesia (ISSI). Dari penjelasan diatas maka pengembangan hipotesis penelitian dapat dirumuskan sebagai berikut.

$\mathbf{H}_{3}$ : Nilai Tukar Rupiah memiliki pengaruh negatif dan signifikan terhadap Indeks Saham Syariah Indonesia (ISSI).

METODE PENELITIAN

Penelitian kuantitatif adalah penelitian empiris dimana data-datanya dalam bentuk sesuatu yang dapat dihitung Punch (1988:4). Penelitian kuantitatif memerhatikan pada pengumpulan dan analisis data dalam bentuk numerik. Desain penelitian ini adalah jenis penelitian kuantitatif dengan melakukan uji hipotesis. Dalam penelitian ini penulis memfokuskan variabel dependen yaitu Indeks Saham Syariah Indonesia (ISSI). Dan variabel independennya difokuskan pada inflasi dan nilai tukar.

Populasi dan sempel dalam penelitian ini adalah perusahaan yang terdaftar dalam Indeks Saham Syariah Indonesia (ISSI) periode Januari 2014 - Desember 2018. Teknik pengambilan sampel yang digunakan yaitu dengan purposive sampling.

\section{HASIL DAN PEMBAHASAN}

\section{Statistik Deskriptif Data}

Hasil statistik data variabel-variabel yang digunakan dalam penelitian ini berdasarkan data mentah Inflasi dan Nilai Tukar Rupiah (Kurs) yang diinput dan diolah dari Bank Indonesia (BI) dengan website www.bi.go.id sedangkan untuk Indeks Saham Syariah Indonesia (ISSI) yang diinput dan diolah dari Bursa Efek Indonesia (BEI) dengan website www.idx.com dan www.duniainvestasi.com.

Tabel 1

Hasil Statistik Deskriptif

\begin{tabular}{llrrr}
\hline & Inflasi & Nilai & \multicolumn{1}{c}{ ISSI } \\
\hline $\mathrm{N}$ & Valid & 60 & 60 & 60 \\
& Missing & 0 & & 0 \\
Mean & 4,6678 & 13267,48 & 169193,60 \\
Std. Deviation & 1,69115 & 868,713 & 14513,191 \\
Minimum & 2,79 & 11404 & 134392 \\
Maximum & 8,36 & 15227 & 197464 \\
\hline
\end{tabular}

Sumber: SPSS, data diolah 2019

\section{Hasil Uji Koefisien Determinasi(R2)}

Koefisien determinasi (R2) pada intinya mengukur seberapa jauh kemampuan model dalam menerangkan variabel dependen (Ghozali, 2009). Apakah R2 $=1$ berarti variabel independent bebas pengaruh secara sempurna terhadap variabel dependen sedangkan apabila $\mathrm{R} 2=0$ berarti variabel independent tidak bebas pengaruh terhadap variabel dependen. Namun banyak peneliti menganjurkan menggunakan Adjusted $\mathrm{R}$ Square hal ini dikarenakan nilai adjusted $\mathrm{R}$ square dapat naik dan turun apabila satu variabel independent ditambahkan ke dalam model.

Tabel 2

Hasil Uji Koefisien Determinasi (R2)

\begin{tabular}{cccccc}
\hline Model & $\mathrm{R}$ & $\mathrm{R}$ Square & $\begin{array}{c}\text { Adjusted R } \\
\text { Square }\end{array}$ & $\begin{array}{c}\text { Std. Error of } \\
\text { the Estimate }\end{array}$ & $\begin{array}{c}\text { Durbin- } \\
\text { Watson }\end{array}$ \\
\hline 1 &, $452^{\mathrm{a}}$ &, 205 &, 176 & 4733,24571 & 1,655 \\
\hline
\end{tabular}

a. Predictors: (Constant), Lag_X2,Lag_X1

b. Dependent Variable: Lag_Y

Sumber: SPSS, data diolah 2019

Hasil analisis regresi berganda dapat diketahui koefisien determinasi (R Square) adalah sebesar 0,205 atau 20,5. Hal ini berarti Hal ini berarti variabel dependen (ISSI) dapat dijelaskan oleh variabel Independen yang terdiri dari Inflasi dan Nilai Tukar sebesar 20,5\% sedangkan sisanya $(100 \%-20,5 \%=$ 
JURNAL AKUNTANSI BISNIS PELITA BANGSA-VOL 5 NO.1 - JUNI 2020

$70,5 \%$ maka dijelaskan oleh sebab atau variabel lain diluar model. Hal ini menunjukan nilai yang kecil sehingga dapat disimpulkan model layak digunakan untuk memprediksi variabel dependen.

\section{Uji Regresi Linear Berganda}

\section{Tabel 3}

Hasil Uji Regresi Linear Berganda

\begin{tabular}{llrr}
\hline & Model & \multicolumn{2}{c}{ Unstandardized Coefficients } \\
& & \multicolumn{1}{c}{ B } & Std. Error \\
\hline 1 & (Constan & 234661,376 & 31374,870 \\
& t) & & \\
& Inflasi & $-5620,176$ & 1095,791 \\
& Kurs & $-2,957$ & 2,133 \\
\hline
\end{tabular}

a. Dependent Variable: ISSI

Sumber: SPSS, data diolah 2019

Berdasarkan hasil perhitungan regresi secara keseluruhan, diperoleh hasil persamaan regresi sebagai berikut :

$$
\text { ISSI }=234661,376-5620,176 \mathrm{X}_{1}-2,957 \mathrm{X}_{2}+31374,870
$$

Model Regresi ini bermakna sebagai berikut :

1. Nilai konstanta sebesar 234661,376 artinya apabila nilai variabel Inflasi dan Nilai Tukar Rupiah (Kurs) bernilai 0, maka Indeks Saham Syariah Indonesia (ISSI) nilainya adalahRp 234.661,376.

2. Koefisien regresi Inflasi sebesar $-5.620,176$ artinya jika variabel independen lain nilainya tatap dan inflasi mengalami kenaikan 1 satuan, maka ISSI akan mengalami penurunan sebesar -5.620,276. Koefisien bernilai negatif artinya terjadi hubungan negatif antara inflasi dengan ISSI, semakin naik inflasi maka semakin turunISSI.

3. Koefisien regresi Kurs sebesar -2,957 artinya jika variabel independen lain nilainya tetap dan kurs mengalami kenaikan 1 satuan, maka ISSI akan mengalami penurunan sebesar -2,957. Koefesien bernilai negatif artinya terjadi hubungan negatif antara kurs dengan ISSI, semakin naiknya kurs maka semakin turunISSI.

4. Nilai error sebesar 31374,870 yang menunjukkan bahwa nilai dari kesalahan pengganggu atau variabel-variabel lain yang tidak dimasukkan dalam model persamaan yaitu sebesar31374,870.

\section{Uji Hipotesis Secara Parsial (Uji t)}

Uji parsial digunakan untuk mengetahui pengaruh masing-masing variabel independen terhadap variabel dependen. Hasil dari uji parsial data dilihat pada tabel berikut ini:

\section{Tabel 4}

Hasil Uji Signifikansi Parsial (Uji-t)

\begin{tabular}{llrrrrr}
\hline \multirow{2}{*}{ Model } & \multicolumn{2}{c}{ Unstndardized Coeffients } & \multicolumn{2}{c}{$\begin{array}{c}\text { Standardized } \\
\text { Coeffients }\end{array}$} & \\
\cline { 3 - 5 } & & \multicolumn{1}{c}{$\mathrm{B}$} & Std. Error & Beta & \multicolumn{1}{c}{ t } & \multicolumn{1}{c}{ Sig. } \\
\hline 1 & (Constant) & 234661,376 & 31374,870 & & 7,479 &, 000 \\
& INFLASI & $-5620,176$ & 1095,791 &,- 655 & $-5,129$ &, 000 \\
& KURS & $-2,957$ & 2,133 &,- 177 & $-1,386$ &, 171 \\
\hline
\end{tabular}

a. Dependent Variable: ISSI

Sumber : SPSS, data diolah 2019

\section{Inflasi(IF)}

Berdasarkan hasil perhitungan tabel 4.1 diatas dapat dilihat bahwa dari total sampel 60, nilai 


\section{JURNAL AKUNTANSI BISNIS PELITA BANGSA-VOL 5 NO.1 - JUNI 2020}

minimum Inflasi selama 5 tahun periode 2014- 2018 adalah sebesar 2,79. Selain itu dari tabel 4.1 terlihat juga nilai maksimum dari variabel Inflasi adalah sebesar 8,36 dan nilai rata-rata sebesar 4,6678, dengan standar deviasi 1,69115.

\section{Nilai Tukar Rupiah(KR)}

Berdasarkan hasil perhitungan tabel 4.1 dapat dilihat bahwa sampel digunakan dalam perhitungan Kurs yakni sebanyak 60 sampel. Dari 60 sampel tersebut menunjukkan bahwa nilai minimum Kurs selama 5 tahun penelitian periode 2014-2018 adalah sebesar 11404. Selain itu dari tabel4.1 terlihat juga nilai maksimum dari variabel Kurs adalah sebesar 15227 dan nilai rata-rata sebesar 13267,48, dengan standar deviasi sebesar 868,713.

\section{Uji Hipotesis Secara Simultan (Uji F)}

Uji f digunakan untuk mengetahui pengaruh simultan variabel independen yaitu inflasi dan nilai tukar secara bersama-sama atau simultan terhadap variabel dependen yaitu Indeks Saham Syariah Indonesia (ISSI).

\section{Tabel 5}

Hasil Uji F

\begin{tabular}{llrll}
\hline Model & Sum of & F & Sig. \\
& & Squares & & \\
\hline 1 & Regression & 4178975172,537 & 14,439 &, $000^{\mathrm{b}}$ \\
& Residual & 8248355331,863 & & \\
& Total & 12427330504,400 & & \\
\hline
\end{tabular}

a. Dependent Variable:ISSI

b. Predictors: (Constant), KURS,INFLASI

Sumber : SPSS, data diolah 2019

Berdasarkan diatas mempunyai F-hitung sebesar 14,439 dengan nilai signifikansi 0,000. Hal ini berarti tingkat nilai signifikan berada di bawah signifikansi 5\% atau lebih kecil dari 0,05 (sig<0,05). Hasil tersebut menunjukkan bahwa variabel inflasi dan nilai tukar rupiah secara simultan atau secara bersama-sama berpengaruh terhadap Indeks Saham Syariah Indonesia (ISSI)(Y).

\section{KESIMPULAN}

Penelitian ini bertujuan untuk mengetahui apakah terdapat pengaruh antara varabel independen yaitu inflasi (X1) dan Nilai Tukar (Kurs) (X2) terhadap Indeks Saham Syariah Indonesia (ISSI) dari bulan Januari 2014 sampai Desember 2018. Penelitian ini menggunakan analisis Regresi Liniear Berganda yang hasilnya dapat ditarik kesimpulan sebagaiberikut:

1. Variabel Inflasi dan Nilai Tukar secara uji f (simultan atau secara bersama-sama) berpengaruh positif terhadap Indeks Saham Syariah Indonesia ditunjukan dengan nilai uji f (Simultan) sebesar 14,439 dan tingkat signifikan $0,000<0,05$.

2. Variabel Inflasi berpengaruh negatif dan signifikan terhadap Indeks Saham Syariah Indonesia (ISSI) ditunjukan dengan nilai uji t sebesar - 5,129 dan tingkat signifikan sebesar 0,000<0,05, sedangkan nilai koefisiennya sebesar-5620,176.

3. Variabel Nilai tukar rupiah (kurs) tidak berpengaruh terhadap Indeks Saham Syariah Indonesia (ISSI) ditunjukan dengan nilai uji t sebesar - 1,386 dan tingkat signifikan 0,171 > 0,05, sedangkan nilai koefisiennya sebesar $-2,957$.

Dalam penelitian ini, terdapat keterbatasan dalam mengungkapkan penelitian yang ada. Beberapa keterbatasan dalam penelitian ini adalah sebagai berikut:

1. Bagi peneliti selanjutnya diharapkan mengikutsertakan variabel lain selain Inflasi dan Nilai Tukar (Kurs), baik itu variabel makroekonomi maupun variabel-variabel internal emiten yang terdaftar 
dalam ISSI. Hal ini penting untuk mengetahui variabel-variabel apa yang sebenarnya memberikan pengaruh signifikan terhadap ISSI, misalkan variabel suku bunga, BI 7 day, dan Jumlah Uang Beredar (JUB).

2. Dalam penelitian ini terdapat masalah autokorelasi, peneliti sudah memakai metode transformasi Cochrane Orcutt di SPSS sehingga nilai uji autokorelasi layak dalam pengujian DurbinWatson.

3. Dalam penelitian ini jumlah sampel yang diteliti masih sedikit yaitu hanya 5 tahun saja, untuk peneliti selanjutnya diharapkan menambah sampel dari awal terbentuk ISSI sampaisekarang.

\section{DAFTAR PUSTAKA}

Agestiani.A dan Sutanto.H.A, (2019). Pengarub Tingkat Suku Bunga, Inflasi, Nilai Tukar, Produk Domestik Bruto, Dan Harga Emas Dunia Terhadap Jakarta Islamic Indeks (JII) periode 2015-2017. Jurnal ekonomi dan perbankkan Vol. 1 No.1 April 2019 Sekolah Tinggi Ilmu Ekonomi Bank BPD Jateng, Semarang

Anggraeni.G.T (2017). Pengarub variabel makroekonomi terhadap Indeks Saham Syariab Indonesia (ISSI) periode Okt 2013 - Sept 2017. Universitas MuhammadiyahSurakarta

Avenda.V.L (2019). Pengarub inflasi, nilai tukar, tingkat imbalan Sertifikat Bank Indonesia Syariah (SBIS), Suku Bunga Bank Indonesia dan Jumlah Uang Beredar (JUB) terbadap Indeks Saham Syariah Indonesia (ISSI) periode 2013 - 2017. Universitas Muhammadi-yah Surakarta

Exchange, Indonesia Stock (2018). Pengantar Pasar Modal. Selasa,20 Ags 2019 I08:20 WIB dari Bursa Efek Indonesia. Web Site:https//www.idx.co.id/investo r/pengantar-pasar-modal/.

Exchange,IndonesiaStock (2018). PengertianIndeksSaham Syariab Indonesia. Selasa,20 Ags 2019 I 08:45 WIB dari Bursa Efek Indonesia. WebSite: https://www.idx.co.id/idx-syariah/indeks-sahamsyariah/

Ghozali, I. (2006). Aplikasi Analisis Multivariate dengan Program SPSS (4th ed.). Semarang: Badan Penerbit Universitas Diponegoro.

Ghozali, I. (2011). Aplikasi Analisis Multivariate dengan Program IBM SPSS. Semarang: Badan Penerbit Universitas Diponegoro.

Hartono, J. (2017). Indeks Saham Syariah Indonesia (ISSI). In Teori Portofolio Dan Analisis Investasi (pp. 177-178). Yogyakarta.

Indonesia,B (2018).Pengenalan Inflasi.16 Ags 2019 dari Bursa Efek Indonesia. WebSite: https://www.bi.go.id/id/moneter/inflasi/pengenalan/Contents/Default.aspx

Indonesia,B (2018). Statistik Saham Syariah ISSI . Selasa,20 Ags 2019 I 16:23 WIB dariOJK.Web Site:https://www.ojk.go.id/id/ka nal/syariah/data-dan- statistik/saham- syariah/default.aspx

Jogiyanto. (2017). Teori Saham. In Teori Portofolio Dan Analisis Investasi (p. 29).Yogyakarta

Karim, A. A. (2015). Nilai Tukar . In Ekonomi Makro Islam (pp. 157-159). Jakarta.

Manurung, M., \& Rahardja, P. (2014). kenaikan harga barang . InTeori Ekonomi Makro (pp. 361362).Jakarta.

Mulyani.N(2012). Analisis pengaruh Inflasi, Suku Bunga, Nilai Tukar Rupiah dan Produk Domestik Bruto Terbadap Jakarta Islamic Index (JII) periode 2009-2011.Universitas terbuka.

Qomariah, S. (2018). Pengaruh Inflasi, Nilai Tukar (KURS), BI 7 Day Repo Rate, Dan Harga Minyak Dunia Terhadap Indeks Saham Syariah Indonesia(ISSI) Tahun 2014-2017.

Raharja, P., \&Manurung, M. (2014). Teori Investasi. In Teori Ekonomi Makro (p. 64). Jakarta.

Suciningtias.S.A dan Khoiroh.R (2015). Analisis Dampak Variabel Makro Ekonomi Terhadap Indeks Saham Syariah Indonesia (ISSI) periode 2011-2014. UNISSULA, ISSN 2302-9791. Vol.2 No.1 May 2015

Sari.M.D.R , Amboningtyas.D dan Fathoni. A (2018). Pengaruh Inflasi, Nilai Tukar, Suku Bunga, dan Jumlah Uang Beredar terhadapIndeks Saham Syariah Indonesia (ISSI) pada Tahun2013-2017

Sartono, R. (2017). Pengertian harga saham. In K. Umum, \& H. Susanto, Manajemen Investasi (p. 177). Bandung: Pustaka Setia.

Solimun, A. A. (2018). In Metodologi Penelitian Kuantitatif Perspektif Sistem (p. 129). Malang.

Solimun, A. A. (2018). Populasi. In Metodologi Penelitian Kuantitatif Perspektif Sistem (p. 133). Malang. 
Solimun, A. A. (2018). Sampel. In Metodologi Penelitian Kuantitatif Perspektif Sistem (p. 136). Malang. Sugiyono, P. D. (2011). In Metode Penelitian Kuantitatif dan R\&D (p. 39). Bandung.

Sugiyono, P. D. (2013), Metodelogi Penelitian Kuantitatif, Kualitatif Dan R\&D. (Bandung:ALFABETA)

Umam, K \& Sutanto,H. (2017). Indeks Saham. In Teori Portopolio Dan Analisis Investasi (p. 177-178).

Umam, K \& Sutanto,H. (2017). Pasar Modal Syariah.Manajemen Investasi(pp. 29-80).

Ulandari.S(2017).PengarubInflasidan NilaiTukar Rupiah Terhadap Harga Sabam Di Sektor Industri Barang Konsumsi Pada Indeks Saham Syariab Indonesia (ISSI)Tabun 2012 - 2016. UIN Raden FatahPalembang

Widyasa.A dan Worokinasih.S (2018). Pengaruh Tingkat Inflasi, Nilai Tukar Rupiah dan Tingkat Suku Bunga Domestik Terbadap Indeks Saham Syariah Indonesia (ISSI)pada tahun 2013-2017. Jurnal Administrasi Bisnis (JAB) Vol. 60 No. 1 juli 2018 administrasibisnis.studentjournal. ub.ac.id 119.

Wahid.A (2018). Analisis Pengaruh Inflasi, TIngkat Suku Bunga, Dan Harga Emas Dunia Terhadap Indeks Harga Saham Di Jakarta Islamic Index (JII) pada tahun2010-2015.Universitas Muhhammadiyah Surakarta.

Yuniarti.D dan Litriani.E (2017). Pengaruh Inflasi Dan Nilai Tukar Rupiah Terhadap Harga Saham Di Sektor Industri Barang Konsumsi Pada Indeks Sabam Syariah Indonesia (ISSI) Tabun 2012-2016. I-Finance Vol.1. No 1.Juli 2017. 